\title{
Bulgaria gets Eastern Europe's first gene release body
}

On August 16, 1996 the Bulgarian National Assembly formally approved the first gene regulatory body in Eastern Europe-the Council for Safe Use of Genetically Modified Higher Plants, part of the Ministry of Agriculture and Food Industry (Sofia). Following the model of regulatory structure set out in the European Union's (EU) "deliberate release" directive $(90 / 220)$, the council has full responsibility for permitting releases (both for research and commercial purposes) on behalf of the ministry and will act as Bulgaria's "competent authority."

The council will have high-level representation: It will be chaired by the deputy minister of agriculture and have five members, including representatives of the ministries of environment and health. The members are appointed by the minister of agriculture. They may invite input from foreign experts where necessary.

Bulgaria thus becomes the first Eastern European country to adopt specific regulations for genetically modified organisms (GMOs). That the new rules encompass only releases of higher plants and products derived from them reflects the need for realpolitik in Eastern Europe. One part of that reality for the former Soviet-bloc nations is that they need to develop technical and trade links in Western Europe. However, organizations in the EU or North America have been unwilling to run field trials anywhere where release regulations corresponding to their own domestic legislation is not in force. According to Pavlin Petrinsky, business development manager at the Institute of Genetic Engineering (IGE, Kostinbrod), one of Bulgaria's leading plant biotechnology centers, at least four Western companies have cited lack of regulations as a barrier to potential collaborations at IGE.

Responding to this kind of dilemma and to pressure from scientific and industrial groups, administrators in Bulgaria-and in Hungary, Poland, and the Czech Republicall have prepared draft regulations covering releases of all classes of recombinant microorganisms. None has yet been approved, however, either because there were more pressing legislative matters, or because of political and public concerns that focus on genetically engineered microorganisms. The Russian parliament came close to approving broad-ranging regulations in 1994, but these, too, ultimately fell.

When these broader proposals faltered, realists in Bulgaria sought a practical compromise: plant-only rules. Plant biotechnology is relatively highly developed in Bulgaria. Although there have been no releases of genetically modified animals or microorganisms, three research field trials with transgenic plants have taken place since 1991. These all concerned plant varieties developed at IGE: Tobacco transformed with the gene that encodes the nucleocapsid of tomato spotted-wilt virus; tobacco resistant to bacterial wild-fire disease ( $P_{\text {seudomonas }}$ syringae pv. Tabaci); and alfalfa transformed with marker genes.

According to Petrinsky, the small size of the council (and its relatively light burden) should ensure efficient operation. Furthermore, the council is obliged to answer every notification within 30 days, either indicating approval or setting out additional conditions that need to be met before a release can be approved.

The plant regulations are regarded within Bulgaria as a prelude to the adoption and ratification by the National Assembly of a complete set of GMO regulations.

John Hodgson

\section{Ecogen Israel gets second approval}

Aspire, Ecogen Israel Partnership's (EIP, Jerusalem) second biocontrol product, was approved in August for use in Israel to control a wide range of postharvest fungi on citrus and apples. A unique formulation of the naturally occurring yeast, Candida oleophila, Aspire received US Environmental Protection Agency (EPA, Washington, DC) approval in February 1995 to prevent rot on harvested citrus and apples. However, it has taken until now for Ecogen to finalize its distribution agreement with the fruit-packing company Decco (Monrovia, CA). Plans for manufacture of Aspire are not yet finalized, but it is likely that it will be produced both in the US and Israel.

EIP is a subsidiary of Ecogen Inc. (Langhorne, PA), acquired in March 1991. It focuses on the development of biofungicides and bionematicides, according to EIP director, Mordecai Keren-Zur, whereas its US parent develops bioinsecticides.

The Aspire product is based on a strain of yeast isolated by Edo Chalutz, deputy director

Vicki Brower is a freelance writer working in New York. of the Agricultural Research Organization (ARO, Rehovot, Israel) and developed in cooperation with US Department of Agriculture (Washington, DC) researcher Charlie Wilson. It acts by colonizing fruit surfacesespecially wounded tissues-and thereby

\section{A unique formulation of the naturally occurring yeast, Candida oleophila, Aspire received US EPA approval in February 1995 to prevent rot on harvested
citrus and apples.}

excludes or inhibits decay pathogens. Formulated as dry, water-dispersible granules, Aspire is sprayed on fruit before waxing. It can be applied in combination with only $5-10 \%$ of the dose of chemicals currently used, reducing fruit contamination and reducing the chance of developing resistance, Keren-Zur said.

One of the reasons for the failure of biocontrol products to thrive on the market has been the difficulty in handling them up until now, which is not a problem with Aspire or EIP's first product, AQ10, a naturally occurring fungus (Ampelocmyces quisqualis) discovered by Hebrew University scientist Abraham Sztejnberg. AQ10, a hyperparasite of all species of powdery mildew on grapes and apples, is still the only biofungicide against powdery mildew, said Keren-Zur. This is its first year of sales, and it is expected to be used primarily by vintners in France and California, where many of its field trials were held. Ecogen recently applied for product registration in France.

Two other biocontrol products are in EIC's pipeline: a bionematocide for the control of root-knot nematodes, which should lower the use of methyl bromide fumigants, increasingly banned due to pernicious soil residues; and a biofungicide to control soil diseases. The first is in early field trials, and the biofungicide is in the planning stage.

Vicki Brower 